\title{
Nutritional evaluation of protein isolate from rubber seed in the diet of Labeo rohita: Effects on growth performance, nutrient utilization, whole body composition and metabolic enzymes activity
}

\author{
Femi John Fawole ${ }^{\mathrm{a}, \mathrm{b}, *}$, Narottam Prasad Sahu ${ }^{\mathrm{a}, *}$, K.K. Jain ${ }^{\mathrm{a}}$, Subodh Gupta ${ }^{\mathrm{a}}$, \\ N. Shamna ${ }^{a}$, Vikas Phulia ${ }^{a}$, D.L. Prabu ${ }^{\mathrm{c}}$ \\ a Fish Nutrition, Biochemistry and Physiology Division, ICAR-Central Institute of Fisheries Education, Mumbai, India \\ ${ }^{b}$ Department of Biological Sciences, Wesley University of Science and Technology, Ondo State, Nigeria \\ ${ }^{\mathrm{c}}$ Marine Biotechnology Division, Central Marine Fisheries Research Institute, Kochi, India
}

\section{A R T I C L E I N F O}

\section{Article history:}

Received 14 March 2016

Received in revised form 3 June 2016

Accepted 17 June 2016

\section{Keywords:}

Rubber seed

Protein isolate

Aquafeed

Growth

Metabolic enzyme

\begin{abstract}
A B S T R A C T
The nutritional potential of protein isolate from rubber seed (RPI) in the diets of Labeo rohita (initial average weight $4.45 \pm 0.01 \mathrm{~g}$ ) was assessed in a 60 days feeding trial. Five isonitrogenous $\left(32.62 \pm 0.13 \mathrm{CP} \mathrm{Kg}^{-1}\right)$ and isocaloric $\left(18.47 \pm 0.08 \mathrm{MJ} \mathrm{kg}^{-1}\right)$ experimental diets were formulated with graded level of RPI like $0 \%, 25 \%, 50 \%, 75 \%$, or $100 \%$ in replacement for soybean protein isolate (SPI), and designated as Control, RPI25, RPI50, RPI75, RPI100, respectively. The RPI contributed $0 \%, 13 \%, 26 \%, 39 \%$ or $52 \%$ of the total dietary protein in the diets. Each diets were randomly assigned to 15 experimental tanks containing 12 fish in triplicates and fed to satiation twice daily at 10:00 h and 18:00 h. At the end of the feeding trial, the growth performance and nutrient utilization indices such as percent weight gain (WG\%), specific growth rate (SGR), daily growth coefficient (DGC), feed intake (FI), protein efficiency ratio (PER), feed conversion ratio (FCR) and protein retention (PR) values were not significantly $(p>0.05)$ affected by the dietary treatments irrespective of inclusion levels of RPI. A significantly higher $(p<0.05)$ hepatosomatic index $(H S I)$ was recorded in the control and RPI 50 group compared to other treatment groups $(\mathrm{p}<0.05)$. The intestinal somatic index (ISI) and Survival rate were similar $(p>0.05)$ in all the groups. The apparent digestibility coefficients (ADCs) of dry matter and protein for fish fed the control and RPI 100 diets were found to be similar, while RPI 50 and RPI 75 groups exhibited a significantly lower value corresponding to the protease enzyme activity. The whole body compositions and digestive/metabolic enzymes activities among the various groups did not differ significantly $(p>0.05)$. The serum cholesterol and triglyceride levels were found to be significantly higher $(p<0.05)$ in the control compared to the RPI fed groups. Significantly higher serum glucose level was recorded in RPI 50, while a reverse was seen in the liver glycogen contents. Overall, this study clearly showed that RPI from rubber seed can serve as alternative protein source in the diets of $L$. rohita fingerlings without any adverse effects on growth, nutrient utilization and physio-metabolic responses.
\end{abstract}

(c) 2016 Elsevier B.V. All rights reserved.

\footnotetext{
* Corresponding author.

E-mail addresses: phem247@yahoo.com (F.J. Fawole), npsahu@cife.edu.in (N.P. Sahu).
} 


\section{Introduction}

The current world population of about 7.3 billion is expected to reach 9.7 billion by 2050 (UN-DESA, 2015), and the global demand for animal protein and hence protein rich feed ingredients for production of animal protein are expected to increase accordingly. Although, aquaculture production continues to grow at a relatively high rate compared to other animal production sector (SOFIA, 2007), but not immune from ingredients shortage occasioned by the high demand and constraint in fish meal production (Tacon and Metian, 2008; Shamna et al., 2015). Aside from the limited availability, the price of the commonly used ingredients is on the rise due to increased demand in the feed of poultry and livestock as well (Coffey et al., 2016). Presently, soybean meal (SBM) is one of the most available plant protein source commonly used in aquafeed production for many fish species including Labeo rohita (El-Sayed, 1999; Storebakken et al., 2000). This is due to the high protein and energy contents, high digestibility and relatively well-balanced amino acid profile of soybean meal (Hertrampf and Piedad-Pascual, 2000; Yue and Zhou, 2008). However, the price of SBM is becoming high and competitive, thereby making it less cost efficient for aquafeed production. Hence, there is the need for its replacement with a potential non-conventional plant protein sources for cost efficient and sustainable aquafeed development. Therefore, in the present scenario, non-edible oil seeds cake or kernel would be one of the most preferred choice provided they are made free of deterrent factors, and nutritionally compatible to cultured species (Marrufo-Estrada et al., 2013; Suprayudi et al., 2015).

Rubber seed cake obtained from rubber tree seed (Hevea brasiliensis) is a potential non-conventional feedstuff, which have received scant research attention is fish nutrition (Alegbeleye et al., 2004; Sharma et al., 2014; Suprayudi et al., 2015; Deng et al., 2015). According to the Natural Rubber Statistic Report (2015), the world natural rubber plantation by acreage in 2014 stand at 12 million hectares. Rubber seeds has enormous potential for aquaculture feed industry if well harnessed. The protein content of rubber seed cake ranges between 17-25\% (Sharma et al., 2014), and are very rich in n-3 and n-6 fatty acid (Eka et al., 2010). Despite the moderate protein content, the nutritive value of rubber seed cake is undermined by the presence of anti-nutritional factors (ANFs) especially cyanogenic glycosides, whose metabolic product is hydrogen cyanide that impacts negatively on the physio-metabolic responses of fish (Francis and Becker, 2001; Sharma et al., 2014; Deng et al., 2015). Other deterrent factors include phytate, tannin, high fiber and complex carbohydrate, which also have detrimental effects on feed palatability, phosphorus availability, digestibility and growth (Watson et al., 2012). However, improvement in plant protein processing technologies has proven to overcome many of these problems, not only by inactivating the anti-nutritional factors or reducing the level of the toxic component but also by improving the nutritional value of the by-products. Many studies have been conducted in this regard, and the concept of protein concentrates/isolates attained relevance in fish nutritional research.

Extraction of protein from defatted seed cake has been described as a way of reducing the contents of antinutrient and toxic components (Marrufo-Estrada et al., 2013) with high levels of protein, which often have digestibility similar or greater than that of fishmeal protein (Makkar et al., 2008). Since rubber kernel meal contain less protein, a large amount of indigestible material and anti-nutrients, there is need to convert them into a better useful products by isolating the protein for optimum utilization. Several studies were conducted recently to explore the inclusion level of various plant protein isolates in fish such as soybean protein isolate in Acipenser schrenckii (Xu et al., 2012), rapeseed (Brassica napus) protein isolate in juvenile Psetta maxima (Nagel et al., 2012), canola (Brassica campestris) protein isolate in Oncorhynchus mykiss (Slawski et al., 2013), jatropha protein isolate in Cyprinus carpio (Kumar et al., 2012; Latif et al., 2015), and pea protein isolate in juvenile Oreochromis niloticus (Schulz et al., 2007). The results from these findings were encouraging, and to the best of our knowledge, no work on protein isolates from rubber seeds has been reported in fish and livestock. With this backdrop, protein isolate was prepared from rubber kernel meal and fed to Labeo rohita (rohu) to assess the potential utilization for aquafeed production. Presently, rohu is the most popular and widely cultured freshwater fish in South-east Asia and command high demand among the consumer. Therefore, $L$. rohita was selected as the candidate species with the aims of investigating the nutritional potential of protein isolate prepared from rubber kernel meal and examine its impact on growth performance, nutrient utilization, whole body composition, digestibility, metabolic enzyme activity, and serum metabolites.

\section{Materials and methods}

\subsection{Production of protein isolate from rubber seed (RPI) and amino acid analysis}

Dried rubber seeds were collected from Tripura $\left(22^{\circ} 56^{\prime} \mathrm{N}-24^{\circ} 32^{\prime} \mathrm{N}, 90^{\circ} 09^{\prime} \mathrm{E}-92^{\circ} 20^{\prime} \mathrm{E}\right)$, India. The seed were dehulled and the kernel obtained were powdered and defatted with hexane (three sequential times) to obtain defatted rubber kernel meal used for the preparation of protein isolate. RPI was prepared by alkali extraction and acid precipitation at its iso-electric point following the method of Saetae and Suntornsuk (2011) with little modification. Ground defatted rubber kernel meal of $2000 \mathrm{~g}$ was dispersed in distilled water in the ratio of $1: 15(\mathrm{w} / \mathrm{v})$. The $\mathrm{pH}$ of the dispersion was adjusted to $12 \mathrm{with} 1 \mathrm{~N} \mathrm{NaOH}$ and stirred for $2 \mathrm{~h}$ at room temperature. The slurry was centrifuged at $7000 \mathrm{rpm}$ for $20 \mathrm{~min}$, and supernatant was collected and adjusted to $\mathrm{pH} 4$ with $1 \mathrm{~N} \mathrm{HCl}$ to precipitate the protein. The precipitated protein was centrifuged and washed twice

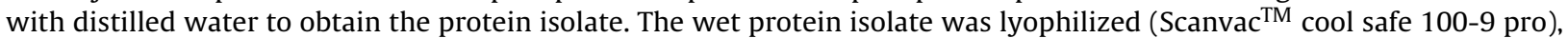
and the final protein content was found to be $908 \mathrm{~g} \mathrm{Kg}^{-1}$ (Table 1). Amino acid analysis was carried out following the method described by Devappa and Swamylingappa (2008), and quantitfied by High performance liquid chromatography (HPLC). 
Table 1

Proximate composition ( $\left.\mathrm{g} \mathrm{kg}^{-1} \mathrm{DM}\right)$, antinutrient contents and amino acid composition of rubber protein isolate (RPI) and soybean protein isolate (SPI).

\begin{tabular}{|c|c|c|c|}
\hline Variables & RPI & SPI & RKM $^{\mathrm{a}}$ \\
\hline Dry matter & 942 & 968 & 940 \\
\hline Crude protein & 908 & 845 & 221 \\
\hline Crude lipid & 15 & 35 & 330 \\
\hline Ash & 20 & 40 & 39 \\
\hline${ }^{\mathrm{C}}$ Total carbohydrate & 57 & 80 & 410 \\
\hline${ }^{\mathrm{d}}$ Gross energy $\left(\mathrm{MJ} \mathrm{kg}^{-1}\right)$ & 23.3 & 23 & 25.6 \\
\hline Indispensable Amino acids ( $\mathrm{g} \mathrm{kg}^{-1}$ ) & & $A A^{\mathrm{b}}$ & \\
\hline Arginine & 109.5 & 67 & - \\
\hline Histidine & 26.4 & 23 & - \\
\hline Isoleucine & 34.1 & 43 & - \\
\hline Leucine & 62.9 & 72 & - \\
\hline Lysine & 16.6 & 55 & - \\
\hline Phenylalanine & 47.2 & 46 & - \\
\hline Methionine & 17.0 & 12 & - \\
\hline Threonine & 30.8 & 33 & - \\
\hline Tryptophan & ND & 12 & - \\
\hline Valine & 78.7 & 44 & - \\
\hline \multicolumn{4}{|l|}{ Dispensable amino acids $\left(\mathrm{g} \mathrm{kg}^{-1}\right)$} \\
\hline Alanine & 33.1 & 38 & - \\
\hline Glycine & 41.5 & 37 & - \\
\hline Aspartate & 102.8 & 102 & - \\
\hline Glutamic acid & 140.5 & 169 & - \\
\hline Proline & 43.8 & 45 & - \\
\hline Serine & 49.6 & 46 & - \\
\hline Cystine & 19.4 & 11 & - \\
\hline Tyrosine & 28.5 & 34 & - \\
\hline \multicolumn{4}{|l|}{ Antinutritional factors } \\
\hline Cyanide ( $\mathrm{mg} \mathrm{HCN} \mathrm{Kg}^{-1}$ ) & 27 & - & 75.6 \\
\hline Phytic acid $\left(\mathrm{g} \mathrm{Kg}^{-1}\right)$ & 15.4 & 14.3 & 31.5 \\
\hline Tannin $\left(\mathrm{g} \mathrm{Kg}^{-1}\right)$ & 0.4 & 8.2 & 5.2 \\
\hline
\end{tabular}

a Rubber kernel meal ( $\left.\mathrm{g} \mathrm{kg}^{-1} \mathrm{DM}\right)$.

b AA - based on company analysis (Soy Growth ${ }^{\mathrm{TM}}$, Medicamen Organics Limited, India) ND - not determine.

c Total carbohydrate $=1000-($ Crude protein + Crude lipid + ash $)$.

d Calculated Gross energy (MJ kg-1) $=\left[23.9 \times \mathrm{CP}\left(\mathrm{g} \mathrm{kg}^{-1}\right)+39.8 \times \mathrm{CL}\left(\mathrm{g} \mathrm{kg}^{-1}\right)+17.6 \mathrm{x} \mathrm{TC}\left(\mathrm{g} \mathrm{kg}^{-1}\right)\right] / 1000$.

\subsection{In vitro protein digestibility}

In vitro protein digestibility assay was carried out by pH-drop method following the method described by Ali et al. (2009). Fresh tissue of alimentary canal was homogenized under cold condition and diluted with distilled water $(1: 10 \mathrm{w} / \mathrm{v})$ followed by centrifuging at $12000 \mathrm{rpm}$ for $15 \mathrm{~min}$ at $4{ }^{\circ} \mathrm{C}$. An equivalent amount of RPI that provided $160 \mathrm{mg}$ of crude protein was weighed and dispersed in $20 \mathrm{~mL}$ of distilled water, and $2 \mathrm{~mL}$ of intestinal homogenenate (enzyme source) to obtain $8 \mathrm{mg}$ crude protein per milliliter, and the $\mathrm{pH}$ was adjusted to 8:00 (Eutop pH tutor, Thermo Fisher Scientific, Singapore). The $\mathrm{pH}$ drop was recorded at every minutes interval for $10 \mathrm{~min}$. Casein was used as the reference protein.

Relative Protein Digestibility was calculated using the following formula:

Relative Protein Digestibility $(\mathrm{RPD} \%)=(\Delta \mathrm{pH}$ of rubber protein isolate $/ \Delta \mathrm{pH}$ of casein $) \times 100$.

\subsection{Diets preparation}

Five experimental diets were prepared to be isonitrogenous $(32.62 \pm 0.13 \% \mathrm{CP})$ and isocaloric $\left(18.47 \pm 0.08 \mathrm{MJ} \mathrm{kg}^{-1}\right)$, with control diet containing soybean protein isolate (SPI) as the major protein source (Table 2). The SPI protein was replaced at $25 \%, 50 \%, 75 \%$, or $100 \%$ with RPI (designated as RPI 25 , RPI 50 , RPI 75 , RPI 100 , respectively). The RPI thereby contributed $0 \%$, $13 \%, 26 \%, 39 \%$ or $52 \%$ of the total dietary protein, respectively. The diets were supplemented with vitamins-mineral mix, and dicalcium phosphate to ensure that all diets satisfied the dietary requirement of L. rohita fingerlings (Debnath et al., 2007). Carboxymethyl cellulose (CMC) was added as a binder and butylated hydroxytoluene (BHT) was incorporated as antioxidant in the diets. All the ingredients were milled and mixed thoroughly to form homogenous blend, then oil and water were added to form dough. The prepared dough was passed through a hand pelletizer using $2 \mathrm{~mm}$ die and the pellets were air dried, and stored at $-20^{\circ} \mathrm{C}$ until use. $\mathrm{A} 5 \mathrm{~g} \mathrm{Kg}^{-1}$ chromium oxide was added to each diet as an inert marker for the estimation of apparent digestibility coefficients (ADC) as described by Hardy and Barrows (2002). 
Table 2

Feed and proximate composition of the experimental diets (DM basis) fed to Labeo rohita fingerlings during the 60 days experimental period.

\begin{tabular}{|c|c|c|c|c|c|}
\hline Ingredients $\left(\mathrm{g} \mathrm{kg}^{-1}\right)$ & $\mathrm{C}$ & RPI25 & RPI50 & RPI75 & RPI100 \\
\hline Soy protein isolate ${ }^{\mathrm{a}}$ & 200 & 150 & 100 & 50 & 0 \\
\hline Rubber protein isolate & 0 & 47 & 93 & 139 & 187 \\
\hline Ground nut cake ${ }^{\mathrm{b}}$ & 126 & 126 & 126 & 126 & 126 \\
\hline Fish meal $^{\mathrm{b}}$ & 50 & 50 & 50 & 50 & 50 \\
\hline Rice bran ${ }^{\mathrm{b}}$ & 240 & 240 & 240 & 240 & 240 \\
\hline Wheat flour & 290 & 293 & 297 & 301 & 303 \\
\hline Sunflower oil:cod liver oil $(1: 1)^{\mathrm{a}}$ & 60 & 60 & 60 & 60 & 60 \\
\hline Dicalcium phosphate $^{c}$ & 10 & 10 & 10 & 10 & 10 \\
\hline Vitamin/mineral mix & 10 & 10 & 10 & 10 & 10 \\
\hline Choline Chloride $^{c}$ & 2 & 2 & 2 & 2 & 2 \\
\hline Butylated hydroxytoluene $^{c}$ & 2 & 2 & 2 & 2 & 2 \\
\hline Carboxymethyl cellulose $^{c}$ & 10 & 10 & 10 & 10 & 10 \\
\hline Total & 1000 & 1000 & 1000 & 1000 & 1000 \\
\hline $\mathrm{Cr}_{2} \mathrm{O}_{3}$ & 5 & 5 & 5 & 5 & 5 \\
\hline \multicolumn{6}{|l|}{ Proximate composition ( $\left.\mathrm{g} \mathrm{kg}^{-1} \mathrm{DM}\right)$} \\
\hline Dry matter & 92.1 & 92.1 & 91.8 & 91.7 & 92.1 \\
\hline Crude protein & 329 & 329 & 323.8 & 323.8 & 325.5 \\
\hline Crude lipid & 62.5 & 62.5 & 65 & 65 & 67.5 \\
\hline Ash & 84.6 & 79.6 & 79.6 & 75 & 75 \\
\hline Crude fibre & 65 & 70 & 70 & 70 & 70 \\
\hline $\mathrm{NFE}^{\mathrm{d}}$ & 459 & 459 & 462 & 466 & 462 \\
\hline Gross energy $\left(\mathrm{MJ} \mathrm{kg}^{-1}\right)^{\mathrm{e}}$ & 18.4 & 18.4 & 18.4 & 18.5 & 18.6 \\
\hline \multicolumn{6}{|l|}{ Antinutritional factors ${ }^{f}$} \\
\hline Cyanide (mg HCN Kg ${ }^{-1}$ ) & 0.00 & 1.27 & 2.51 & 3.75 & 5.05 \\
\hline Phytic acid $\left(\mathrm{g} \mathrm{kg}^{-1}\right)$ & 2.86 & 2.87 & 2.86 & 2.86 & 2.88 \\
\hline Tannin $\left(\mathrm{g} \mathrm{kg}^{-1}\right)$ & 1.64 & 1.25 & 0.86 & 0.47 & 0.07 \\
\hline
\end{tabular}

Composition of vitamin-mineral mix (PRE-EMIX PLUS) (quantity/kg): Vitamin A, 55, 00000 IU; Vitamin B, 2 000 mg; Vitamin D3, 11,00 000 IU; Vitamin E, 750 mg; Vitamin K, 1000 mg; Vitamin B6, 1000 mg; Vitamin B1, 2,6 mcg; Calcium Pantothenate,2500 mg; Nicotinamide, 10 g; Mn, 27 000 mg; I, 1000 mg; Fe, 7500 mg; Zn, 5000 mg; Cu, 2000 mg; Co, 450; L-lysine, 10 g; DL-Methionine, 10 g; Selenium, 125 mg.

a Soy Growth ${ }^{\mathrm{TM}}$, Medicamen Organics Limited, India.

b Purchased from local animal feed ingredient dealer, Mumbai, India.

c Himedia Pvt, Mumbai, India.

d NFE (Nitrogen free extract) $=1000-($ Crude protein + Crude lipid + crude fibre + ash $)$.

e Calculated gross energy $\left(\mathrm{MJ} \mathrm{kg}{ }^{-1}\right)=\left[23.9 \times \mathrm{XP}\left(\mathrm{g} \mathrm{kg}^{-1}\right)+39.8 \times \mathrm{xL}\left(\mathrm{g} \mathrm{kg}^{-1}\right)+17.6 \mathrm{x} \mathrm{NFE}\left(\mathrm{g} \mathrm{kg}^{-1}\right)\right] / 1000$.

f Calculated based on cyanide, phytic acid and tannin concentration in RPI, and SPI.

\subsection{Experimental set-up}

Rohu (Labeo rohita) fingerlings were obtained from Srushti Aquaculture, Sudhagad, Raigad District, Maharashtra, India, and transported to the wet laboratory of the Division of Fish Nutrition, Biochemistry and Physiology, ICAR-Central Institute of Fisheries Education, Mumbai. Fish were carefully transferred to two circular fibre tank (1000 L) for acclimatization under aerated condition and fed with control diets. One hundred and eighty rohu fingerlings were randomly distributed in 15 plastic rectangular tubs ( $75 \mathrm{~L}$ capacity) each containing 12 fish (initial average weight $4.45 \pm 0.01 \mathrm{~g}$ ) per tank, in triplicates. Fish were hand fed with their respective diets to apparent satiation twice daily at 10:00 h and 18:00 h under normal light regime. The fish in each tub were weighed at the start and every two weeks over a period of 60 days. The fish were not fed on the day of weighing. Water quality parameters were monitored and maintained at optimal level (temperature $25-29^{\circ} \mathrm{C}$; pH 7.5-8.1; DO 6.3-7.5 mg/l; ammonia 0.05-0.09 ppm). Prior to the commencement of the feeding trial, a total of 15 fish were sacrificed and stored at $-20^{\circ} \mathrm{C}$ for the analysis of initial whole body composition.

\subsection{Fish sampling and chemical analysis}

Fish were fasted for $24 \mathrm{~h}$ on the completion of 60 days feeding trial, weighed and the growth performance and nutrient utilization parameters like percent weight gain(WG\%), specific growth rate (SGR), daily growth coefficient (DGC), feed intake (FI), protein efficiency ratio (PER), feed conversion ratio (FCR) and protein retention (PR) were calculated according to the formulae given beneath Table 3. Difference in number of fish stocked at the beginning and end of the experimental trial were determined for calculation of survival. The liver and intestine from six fish per treatment were pooled together and weighed for the calculation of hepatosomatic index (HSI) and intestinal somatic index (ISI). Three fish from each tank were sampled for the analysis of whole body composition. The moisture, crude protein, crude lipid and ash content in the diets and whole body were carried out as per the standard methods of the Association of Official Analytical Chemists (AOAC, 1995). Moisture was determined after drying in an oven at $105^{\circ} \mathrm{C}$ until constant weight. Ash content was determined by muffle furnace at $550^{\circ} \mathrm{C}$ for $6 \mathrm{~h}$. Crude protein content $(\mathrm{N} \times 6.25)$ was determined by the Kjeldahl method after acid digestion using an Auto Kjeldahl System (2200 Kjeltec auto distillation; Foss Tecator, Hoganas Sweden). Crude lipid was determined 
Table 3

Growth performance, nutrient utilization, survival and apparent digestibility coefficient of Labeo rohita fingerlings fed different experimental diets.

\begin{tabular}{|c|c|c|c|c|c|c|c|c|c|}
\hline \multirow[t]{2}{*}{ Variables } & \multicolumn{5}{|l|}{ Diets } & \multirow[t]{2}{*}{ SEM $^{\mathrm{a}}$} & \multicolumn{3}{|l|}{ P-values } \\
\hline & Control & RPI 25 & RPI 50 & RPI 75 & RPI 100 & & Overall & Linear & Quadratic \\
\hline Weight gain $(\%)^{b}$ & 131.66 & 121.04 & 114.28 & 117.08 & 121.39 & 4.485 & 0.147 & 0.115 & $0.041^{*}$ \\
\hline $\mathrm{SGR}^{\mathrm{C}}$ & 1.40 & 1.32 & 1.27 & 1.29 & 1.32 & 0.034 & 0.151 & 0.115 & $0.043^{*}$ \\
\hline $\mathrm{FI}^{\mathrm{d}}$ & 6.08 & 5.98 & 5.83 & 5.93 & 6.16 & 0.148 & 0.584 & 0.837 & 0.133 \\
\hline $\mathrm{DGC}^{\mathrm{e}}$ & 3.24 & 3.00 & 2.83 & 2.90 & 3.01 & 0.114 & 0.185 & 0.148 & 0.050 \\
\hline PER $^{\mathrm{f}}$ & 1.98 & 1.90 & 1.87 & 1.87 & 1.85 & 0.070 & 0.688 & 0.202 & 0.600 \\
\hline $\mathrm{FCR}^{\mathrm{g}}$ & 1.55 & 1.61 & 1.65 & 1.64 & 1.66 & 0.059 & 0.661 & 0.189 & 0.552 \\
\hline Protein retention $^{\mathrm{h}}$ & 33.77 & 32.03 & 31.49 & 31.54 & 31.49 & 1.974 & 0.905 & 0.436 & 0.603 \\
\hline $\mathrm{HSI}^{\mathrm{i}}$ & 0.88 & 0.70 & 0.76 & 0.64 & 0.65 & 0.042 & $0.014^{*}$ & $0.003^{*}$ & 0.259 \\
\hline ISI $^{\mathrm{j}}$ & 2.99 & 2.47 & 2.10 & 2.22 & 2.01 & 0.304 & 0.233 & $0.045^{*}$ & 0.353 \\
\hline Survival $^{\mathrm{k}}$ & 100 & 97.22 & 100 & 100 & 97.22 & 1.756 & 0.580 & 0.628 & 0.682 \\
\hline $\mathrm{ADC}$ of $\mathrm{DM}^{\mathrm{l}}$ & 67.04 & 63.03 & 62.01 & 63.22 & 67.98 & 0.648 & $0.004^{*}$ & 0.359 & $<0.001^{*}$ \\
\hline $\mathrm{ADC}$ of protein & 85.27 & 86.24 & 80.49 & 80.97 & 84.51 & 0.236 & $<0.001^{*}$ & $<0.001^{*}$ & $<0.001^{*}$ \\
\hline ADC of lipid & 89.44 & 88.17 & 72.37 & 71.56 & 85.75 & 6.343 & 0.247 & 0.285 & 0.111 \\
\hline $\mathrm{ADC}$ of $\mathrm{P}^{\mathrm{m}}$ & 40.02 & 45.26 & 39.63 & 39.25 & 40.87 & 0.729 & $0.010^{*}$ & 0.121 & 0.495 \\
\hline Liver glycogen $^{\mathrm{n}}$ & 33.18 & 35.10 & 23.34 & 50.26 & 50.06 & 3.626 & $0.001^{*}$ & $0.002^{*}$ & $0.033^{*}$ \\
\hline
\end{tabular}

* Estimated Marginal Means $(\mathrm{P}<0.05)$

a Standard error of the mean.

b Weight gain\% = (final body weight - initial body weight $) /$ initial body weight $\times 100$.

c Specific growth rate (SGR, \%/day) $=100 \times($ ln final body weight-ln initial body weight)/experimental duration in days.

d Feed intake $\left(\mathrm{g} \mathrm{kg}^{-1} \mathrm{MBW} /\right.$ day)=total dry feed given per fish ( $\mathrm{g}$ fish $\left.{ }^{-1}\right) / \mathrm{MBW} / \mathrm{experimental}$ duration in days; mean metabolic body weight $(\mathrm{MBW})=\left\{(\text { initial body weight in } \mathrm{g} / 1000)^{0.75}+(\text { final body weight in } \mathrm{g} / 1000)^{0.75}\right\} / 2$ (Deng et al., 2015).

e Daily growth coefficient $\left(\right.$ DGC, $\%$ days $\left.^{-1}\right)=100 \times\left\{(\text { final body weight in } g)^{1 / 3}\right.$-(initial body weight in $\left.\left.g\right)\right\}^{1 / 3} /$ experimental duration in days

${ }^{\mathrm{f}}$ Protein efficiency ratio (PER) $=$ Net weight gain $(\mathrm{g}) /$ protein fed $(\mathrm{g})$.

$\mathrm{g}$ Feed conversion ratio $(\mathrm{FCR})=$ total dry feed given $(\mathrm{g}) /$ wet weight gain $(\mathrm{g})$.

h Protein retention $(P R)=100 x\{$ (final body weight $x$ final body protein content) - (initial body weight $\times$ initial body protein content $)\} /($ protein content in diet $\times$ total feed intake).

${ }^{\mathrm{i}}$ Hepatosomatic index (HSI) $=100 \mathrm{x}$ wet weight of liver $(\mathrm{g}) /$ whole body weight of fish $(\mathrm{g})$.

$\mathrm{j}$ Intestinal somatic index (ISI) $=100 \mathrm{x}$ wet weight of intestine $(\mathrm{g}) /$ whole body weight of fish $(\mathrm{g})$.

k Survival $(\%)=100 \mathrm{x}$ (total number of fish harvested)/(total number of fish stocked).

${ }^{1}$ ADC - Apparent digestibility coefficient; DM- Dry matter.

$\mathrm{m}$ P- Phosphorus.

n (mg/g wet tissue).

by the ether-extraction method in a soxhlet extraction apparatus (Socsplus, SCS-08-As, Pelican equipment, Chennai, India). The cyanide content of the RPI was analysed according to alkaline titration method of AOAC (2000), phytic acid and tannin contents were analysed as per the method of Gao et al. (2007) and Schanderi (1970), respectively.

\subsection{In vivo digestibility}

Faecal samples were collected daily by siphoning for 15 days ( 45 to 60th day). Three hours after feeding each day, the tanks were checked for uneaten feed, but there was no feed left out in the tubs. Faecal sample were collected $7 \mathrm{~h}$ after feeding, centrifuged at $5000 \mathrm{rpm}$ for $15 \mathrm{~min}$ to separate the water, the wet faecal sample was stored at $-20^{\circ} \mathrm{c}$ and lyophilized. Analysis of crude protein and lipid contents were carried out according to AOAC (1995) and chromium content of feed and faecal matters was determined by the method of Furukawa and Tsukahara (1966). The apparent dry matter digestibility of diets and nutrients were calculated according to Law (1986): ADC of dry matter of diet (\%) $=100 \times\left\{1-\left(\% \mathrm{Cr}_{2} \mathrm{O}_{3}\right.\right.$ in feed $) /\left(\% \mathrm{Cr}_{2} \mathrm{O}_{3}\right.$ in faeces $\left.)\right\}$; ADC of Nutrients/phosphorus in the diets $(\%)=100 \times\left[1-\left\{\left(\% \mathrm{Cr}_{2} \mathrm{O}_{3}\right.\right.\right.$ in feed $/ \% \mathrm{Cr}_{2} \mathrm{O}_{3}$ in faeces $) \times(\%$ Nutrients/phosphorus in faeces/(\% Nutrients/phosphorus in feed)\}].

\subsection{Serum biochemistry and enzyme assay}

After $24 \mathrm{~h}$ of fasting, blood samples were collected from randomly selected fish (four from each replicate). The fish were anaesthetized with clove oil ( $50 \mu \mathrm{L}$ of clove oil per litre of water; Debnath et al., 2007) and blood was collected from the caudal vein without anticoagulant into a dried eppendorf tube and allowed to stand in a slanted position at room temperature. The blond were centrifuged at $5000 \mathrm{~g}$ for $10 \mathrm{~min}$ in a cooling centrifuge (REMI CPR-24, India), and transferred into another eppendorf tube and kept in $-20^{\circ} \mathrm{C}$ until use. Serum cholesterol, triglyceride and glucose were estimated using a commercial kit (Erba ${ }^{\circledR}$ Diagnostic Mannheim, Transasia Bio-medicals Ltd, Solan, HP, India). The liver, muscle and intestinal tissues were dissected out and homogenized in cold $0.25 \mathrm{M}$ sucrose solution in $15 \mathrm{~mL}$ plastic tubes using a Teflon-coated mechanical homogenizer (MICCRA D-9, ART Prozess and Labortechnik, Germany). The tubes were continuously kept in ice to avoid heating. The homogenate was centrifuged ( $5000 \mathrm{~g}$ for $10 \mathrm{~min}$ at $4^{\circ} \mathrm{C}$ ) and the supernatant stored at $-20^{\circ} \mathrm{C}$ until analysis. The protease enzyme activity was determined by the casein digestion method (Drapeau, 1974). Amylase activity was estimated as the reducing sugars produced due to the action of glucoamylase and $\alpha$-amylase on carbohydrate using dinitro- 
salicylic-acid method (Rick and Stegbauer, 1974). The aspartate amino transferase (AST) and alanine amino transferase (ALT) activities were measured by the method described by Wooten (1964). Lactate dehydrogenase (LDH) enzyme activity was measured following the method of Wroblewski and Ladue (1955). Protein contents of the tissues were determined according to Bradford (1976), adapted to microplate in other to express enzyme activities as a function of the protein content. Bovine serum albumin was used as the protein standard.

\subsection{Hepatic glycogen content}

Liver glycogen content was estimated colorimetrically by the method described by Hassid and Abraham (1957). The tissue was digested with $30 \% \mathrm{KOH}$ and $95 \%$ ethanol was added. Glycogen was precipitated upon centrifugation at $5000 \mathrm{~g}$ for 5 min, which was dissolved in distilled water. To a known quantity of aliquot, anthrone reagent was added and mixed by swirling the tube. The tubes were covered with glass marble and heated for $10 \mathrm{~min}$ in boiling water followed by cooling. The absorbance was recorded at $590 \mathrm{~nm}$. The reading was compared with standard glycogen and expressed as $\mathrm{mg} / \mathrm{g}$ wet tissue.

\subsection{Statistical analysis}

All data were subjected to a one way ANOVA using the General Linear Model Procedure of IBM SPSS package, version 20. The overall treatments effects were determined and polynomial contrasts were used to test linear and quadratic effects of dietary inclusion of RPI. Significance was defined at $\mathrm{P}<0.05$.

\section{Results}

\subsection{Protein isolate production, antinutritional factors and in vitro protein digestibility}

The protein, lipid, ash and carbohydrate contents of the RPI were found to be $908,15,20$ and $57 \mathrm{~g} \mathrm{~kg}^{-1}$, respectively (Table 1). The protein content of RPI increased more than threefold with a corresponding decrease in the lipid, fibre and total carbohydrate contents compared to the rubber kernel meal (RKM). The cyanide, phytic acid and tannin contents estimated in the RKM $\left(75.6,31.5,5.2 \mathrm{~g} \mathrm{~kg}^{-1}\right.$, respectively) and RPI $\left(27,15.4,0.4 \mathrm{~g} \mathrm{~kg}^{-1}\right.$, respectively) samples are given in Table 1 . The amino acid composition of RPI is comparable to that of soybean protein isolate (SPI) except lysine, which is lower in RPI. The RPI protein digestibility in vitro was found to be $93.2 \%$.

\subsection{Growth performance, nutrient utilization and survival rate}

After the 60 days feeding trial, the weight gain (\%), SGR, DGC, PER, PR and FCR values did not differ significantly among the various groups $(p>0.05)$ and no linear trend was observed (Table 3$)$. However, weight gain (\%) and SGR values showed a quadratic trend $(P<0.05)$. The HSI value showed overall significant effects $(\mathrm{p}<0.05)$ and followed linear trends. The ISI and fish survival rate were not significantly $(p>0.05)$ affected as a result of feeding RPI. Overall, the groups of fish fed RPI-based diets showed similar performance in terms of growth and nutrient utilization with the control group.

\subsection{Apparent digestibility coefficients (ADC)}

The apparent digestibility coefficient of dry matter showed similar value between the fish fed control and RPI 100 diets (Table 3), whereas RPI 50 and RPI 75 fed groups registered a significantly lower value $(p<0.05)$. The ADC of protein showed both linear and quadratic effects, with the highest value recorded in RPI 25. Similar results were recorded in ADC of phosphorus with a significantly higher value recorded in RPI 25, but showed no linear and quadratic trends. Nonetheless, phosphorus digestibility was observed to be lower in all the groups (39.25\%-45.26\%). No significant variation was observed in the ADC of lipid (71.56\%-89.44\%) among the various groups ( $p>0.05)$.

\subsection{Whole body composition}

The dietary inclusion of RPI showed no significant difference $(p>0.05)$ in the whole body composition of the treatment groups compared with the control (Table 4). The initial fish body composition showed higher ash content compared to the experimental fish (final body ash), wherein the reverse was found in the case of protein and lipid contents.

\subsection{Digestive and metabolic enzyme activitivies, serum metabolites and liver glycogen contents}

There was no significant difference $(p>0.05)$ in the protease $\left(0.37-0.47 \mathrm{U} \mathrm{mg}^{-1}\right.$ protein) and amylase $(0.99-1.32)$ enzymes activities among the various groups (Table 5). The activities of the metabolic enzymes (AST, ALT and LDH) in the liver and muscle were not significantly ( $p>0.05$ ) affected as a result of feeding RPI, and no observable trends recorded (Table 6 ). The cholesterol and triglyceride levels in the serum were found to be significantly higher $(p<0.05)$ in the control compared to the RPI fed groups (Table 5). The serum cholesterol level tends to decrease linearly with the increasing dietary RPI levels, 
Table 4

Whole body (wet weight basis) composition of Labeo rohita fingerlings fed different experimental diets.

\begin{tabular}{|c|c|c|c|c|}
\hline \multirow[t]{2}{*}{ Diets } & \multicolumn{4}{|l|}{ Variables } \\
\hline & Moisture & Crude protein & Crude lipid & Ash \\
\hline Control & 70.72 & 15.46 & 7.82 & 2.61 \\
\hline RPI 25 & 73.62 & 15.28 & 6.36 & 2.76 \\
\hline RPI 50 & 72.25 & 15.17 & 7.31 & 2.71 \\
\hline RPI 75 & 72.36 & 15.24 & 6.08 & 2.80 \\
\hline RPI 100 & 73.04 & 15.38 & 6.11 & 2.92 \\
\hline SEM $^{\mathrm{a}}$ & 0.666 & 0.413 & 0.585 & 0.148 \\
\hline Overall & 0.096 & 0.988 & 0.208 & 0.686 \\
\hline Linear & 0.140 & 0.885 & 0.075 & 0.198 \\
\hline Quadratic & 0.264 & 0.607 & 0.724 & 0.900 \\
\hline
\end{tabular}

Initial fish - 79.42 moisture; 13.35 crude protein; 2.28 crude lipid; 3.91 ash.

Estimated Marginal Means $(\mathrm{P}<0.05)$.

a Standard error of the mean.

Table 5

Intestinal protease and Amylase, serum cholesterol (mg/dl), serum triglyceride (mg/dl), and serum glucose (mg/dl) levels in Labeo rohita fingerlings fed different experimental diets.

\begin{tabular}{|c|c|c|c|c|c|}
\hline \multirow[t]{2}{*}{ Diets } & \multicolumn{5}{|l|}{ Variables } \\
\hline & Protease $^{\mathrm{b}}$ & Amylase $^{c}$ & Cholesterol & Triglyceride & Glucose \\
\hline Control & 0.47 & 1.32 & 92.70 & 132.95 & 105.47 \\
\hline RPI 25 & 0.47 & 0.99 & 84.13 & 124.90 & 116.41 \\
\hline RPI 50 & 0.41 & 1.00 & 77.46 & 110.73 & 124.84 \\
\hline RPI 75 & 0.37 & 1.00 & 79.37 & 111.11 & 81.21 \\
\hline RPI 100 & 0.45 & 1.12 & 73.33 & 122.99 & 111.02 \\
\hline $\mathrm{SEM}^{\mathrm{a}}$ & 0.025 & 0.233 & 3.914 & 4.504 & 2.208 \\
\hline Overall & 0.104 & 0.834 & $0.046^{*}$ & $0.025^{*}$ & $<0.001$ \\
\hline Linear & 0.130 & 0.605 & $0.006^{*}$ & $0.039^{*}$ & 0.006 \\
\hline Quadratic & 0.119 & 0.344 & 0.373 & $0.009^{*}$ & 0.114 \\
\hline
\end{tabular}

* Estimated Marginal Means $(\mathrm{P}<0.05)$.

a Standard error of the mean.

b Protease: U mg protein ${ }^{-1}$.

c Amylase specific activity expressed as micromole of maltose released $\mathrm{min}^{-1} \mathrm{~g}$ protein $^{-1}$.

Table 6

Metabolic enzymes activity in the liver and muscle of Labeo rohita fingerlings fed different experimental diets.

\begin{tabular}{|c|c|c|c|c|c|c|}
\hline \multirow[t]{3}{*}{ Diets } & \multicolumn{6}{|c|}{ Variables } \\
\hline & \multicolumn{2}{|l|}{ ALT } & \multicolumn{2}{|l|}{ AST } & \multicolumn{2}{|l|}{$\mathrm{LDH}$} \\
\hline & Liver & Muscle & Liver & Muscle & Liver & Muscle \\
\hline Control & 2.11 & 9.34 & 14.06 & 15.31 & 3.25 & 2.04 \\
\hline RPI 25 & 2.87 & 8.92 & 17.72 & 15.42 & 3.71 & 1.78 \\
\hline RPI 50 & 1.99 & 8.63 & 15.50 & 12.86 & 2.63 & 1.88 \\
\hline RPI 75 & 2.04 & 9.06 & 17.00 & 14.37 & 3.07 & 1.49 \\
\hline RPI 100 & 1.93 & 9.96 & 16.44 & 13.96 & 2.76 & 1.31 \\
\hline SEM $^{\mathrm{a}}$ & 0.274 & 0.650 & 1.154 & 1.097 & 0.372 & 0.509 \\
\hline Overall & 0.168 & 0.671 & 0.270 & 0.491 & 0.324 & 0.845 \\
\hline Linear & 0.199 & 0.520 & 0.293 & 0.306 & 0.199 & 0.300 \\
\hline Quadratic & 0.442 & 0.198 & 0.298 & 0.477 & 0.982 & 0.864 \\
\hline
\end{tabular}

Estimated Marginal Means $(\mathrm{P}<0.05)$.

Alanine transaminase (ALT): specific activities expressed as nanomoles of sodium pyruvate formed $\mathrm{mg}^{\text {protein }}{ }^{-1} \mathrm{~min}^{-1}$ at $37^{\circ} \mathrm{C}$; Aspartate transaminase (AST): specific activities expressed as nanomoles of oxaloacetate released $\mathrm{min}^{-1} \mathrm{mg} \mathrm{protein}^{-1}$ at $37^{\circ} \mathrm{C}$. Lactate dehydrogenase (LDH): specific activity expressed as Units min $^{-1} \mathrm{mg}$ protein ${ }^{-1}$ at $37^{\circ} \mathrm{C}$.

a Standard error of the mean.

but showed no quadratic effects $(p>0.05)$. Highest triglyceride level was detected in the control group, which was found to follow linear and quadratic trends $(p<0.05)$. Significantly higher serum glucose level was recorded in RPI 50 and lowest in RPI 75 fed group $(\mathrm{p}<0.05)$. The liver glycogen contents showed both linear and quadratic effects, with the highest value recorded in RPI $75(50.26 \pm 0.66)$ and RPI $100(50.06 \pm 1.77)$ groups, while the group fed RPI $50(23.34 \pm 2.01)$ registered the lowest value $(\mathrm{P}<0.05)$ (Table 3$)$. 


\section{Discussion}

Improving the nutritional quality of plant protein ingredients for efficient utilization requires innovative approach for sustainable aquafeed production. Isolation of protein is one of such approach by separating the pure protein fractions from other non-proteinaceous components present in the ingredients including antinutritional factors (Mwachireya et al., 1999; Devappa and Swamylingappa, 2008; Saetae and Suntornsuk, 2010; Wanasundara, 2011), thus improve the digestibility and nutrient utilization. In the present study, the protein content of the isolated protein (RPI) from rubber kernel meal was found to be $908 \mathrm{~g} \mathrm{~kg}^{-1}$ with a concomittant reduction in the cyanide contents (64.3\%), phytic acid (51.1\%), tannin (92.4\%) and insoluble carbohydrate. De-hulling the rubber seeds and subsequent treatment with alkali seems to help in reducing the tannin contents to a very low levels as recommended by Griffiths (1991). The cyanide content in $\left.\mathrm{RPI}^{(27} \mathrm{mg} \mathrm{kg}^{-1}\right)$ was less than the value reported for detoxified rubber kernel meal ( $60.1 \mathrm{mg} \mathrm{kg}^{-1}$ ) fed to L. rohita fingerling (Sharma et al., 2014 ). The protein content of RPI was similar to canola protein isolate (Mwachireya et al., 1999), but more than those reported by for rapeseed protein isolate (Nagel et al., 2012), pea protein isolate (Schulz et al., 2007), canola protein isolate (Slawski et al., 2013) and jatropha protein isolate (Kumar et al., 2012). Isolating the proteins from rubber kernel meal resulted in a significant increase in the protein content and reduction in the antinutritional factors as reported by other researchers in different studies (Devappa and Swamylingappa 2008; Saetae and Suntornsuk, 2010; Nagel et al., 2012; Kumar et al., 2012; Slawski et al., 2013). The higher in vitro digestibility of RPI recorded in this study may be due to the significant reduction in the soluble and indigestible carbohydrates, antinutritional factors, and more accessibility of amino acid peptide bonds by the digestive enzymes as reported by Devappa and Swamylingappa (2008). Protein isolate (RPI) obtained in this study exhibited lower in vitro digestibility values than casein (97\%), but more than rapeseed (83\%) and jatropha protein isolates (88.5-90.6\%) (Savoie et al., 1988; Devappa and Swamylingappa, 2008).

Although, rubber seed meal has been reported to be a promising alternative protein source for aquafeeds production (Sharma et al., 2014; Suprayudi et al., 2015; Deng et al., 2015), but utilization by fish is limited due to the presence of ANFs, especially cyanide. According to Deng et al. (2015), feeding rubber seed meal above 30\% to juvenile tilapia (Oreochromis niloticus $x$ O. aureus) lead to growth depression, which was also supported by Alegbeleye et al. (2004). Contrarily, defatted rubber seed meal successfully replaced 50\% of the protein in common carp (Cyprinus carpio) diets without adverse effects on the feed intake and growth (Suprayudi et al., 2015). The variation in their results may be due to the levels of ANFs, nonstarch polysaccharide, and or species differences. Literature have shown that varying level of antimetabolites, indigestible carbohydrates, amino acid imbalances and other complexes may contribute to growth depression often observed when plant protein ingredients are fed at higher inclusion levels to fish, rather than pinpointing one single factor as the primary reason for the adverse effects noticed (Mambrini et al., 1999; Francis and Becker, 2001; Schulz et al., 2007; Slawski et al., 2013; Shamna et al., 2015). However, in the present study, no significant variation was observed in the growth performance of the fish fed RPI in replacement for SPI. This indicate that RPI was better utilized compared to detoxified rubber seed meal fed to rohu (Sharma et al., 2014), and other fish species (Suprayudi et al., 2015; Deng et al., 2015). The presence of ANFs in plant-based diets is one of the reason for diminishing feed intake, nutrient absorption and growth depression in fish due to unpleasant tastes, and decreased feed acceptability (Francis and Becker, 2001). Conversely, the inclusion of RPI in the diets of rohu as seen in this study did not cause any decrease in feed intake. Rather, the RPI 100 fed group recorded the highest feed intake, though not differ from other fed groups, indicating that diets palatability and acceptability were not affected. Our findings are in consonant with Slawski et al. (2013) and Kumar et al. (2012), who observed no significant difference in the feed intake of rainbow trout and common carp fed canola and jatropha protein isolates, respectively. Sharma et al. (2014) reported that feeding RKM diets containing a high level of cyanide $\left(>39 \mathrm{mg} \mathrm{kg}^{-1}\right)$ to rohu led to a reduction in protein utilization and digestion processes, which resulted in poor growth performance. Similar result was observed (31.8 mg kg-1 diets) in the work of Deng et al. (2015). However, feeding RPI in the present study showed no adverse effect on the nutrient utilization, protein accretion, and digestion processes. This can be attributed to the low level of cyanide (1.27-5.05 mg kg $\left.{ }^{-1}\right)$ (Table 2) in the diets of the present study, which was below the levels reported to cause no adverse effects in earlier studies. The lack of differences in the PER, FCR and PR indicate that the RPI was well digested, absorbed and utilized by the fish for muscle growth. Also, the insignificant differences in the feed intake signifies that RPI can be accepted by rohu without any palatability-mediated feed rejection.

HSI value can be correlated with the amount of fat or glycogen deposition (Gao et al., 2012; Debnath et al., 2007). In the present study, significantly higher HSI value was recorded in the control and RPI 50 fed groups compared to others, which indicate higher lipid deposition in the liver. Increased hepatic lipogenic enzymes activities has been reported in European seabass fed soybean protein concentrates or corn gluten meal, thereby, leads to higher whole body lipid composition (Dias 1999; Kaushik et al., 2004). This may be the reason for the higher HSI value recorded in control (0.88) and RPI 50 (0.76) fed groups. The trends in both the HSI value and whole body lipid contents follow a similar pattern $(y=0.1216 \times-0.0934$, $\left.r^{2}=0.94\right)$. This was further supported by Gao et al. (2012) who found a correlation between HSI value and amount of fat deposition in the body of red sea bream fed diets devoid of vitamin E. Similar results have also been reported in common carp fed plant protein based diets (Kumar et al., 2012). Paradoxically, our data revealed higher glycogen contents in fish fed RPI 75 and RPI 100. As observed in the work of Suprayudi et al. (2015), the groups of fish showing high HSI value recorded low lipid and high glycogen contents in the hepatopancreas, while the groups with lower HSI value showed opposite trend after fed rubber seed meal based diets. Our findings are in opposite to this, wherein we observed that the groups with higher HSI value recorded high lipid and low glycogen contents. This shows that an inverse relationship may exists between 
lipid and glycogen deposition in fish, but further study is required in this aspect. The non-significant difference observed in the ISI value among the experimental groups, indicates that the physiological well-being of the digestive system was not compromised as a result of feeding RPI. These findings are in accord with Kumar et al. (2012) who observed a significantly higher ISI in fish fed plant protein (soybean and jatropha protein isolates) based diets compared with fishmeal fed group.

Apparent digestibility coefficients of protein and phosphorus in L. rohita fingerlings fed practical diets with varying levels of microbial phytase ranged between 73.90-82.13\% and 52.08-65.39\%, respectively (Baruah et al., 2007). However, higher value was recorded in the present study, with ADC of protein in RPI-fed groups ranging between $80.49-86.24 \%$. Although RPI 50 and RPI 75 recorded the lowest values compared to other fed groups, but no significant impact was found on the protein retention and growth performance, which indicates that the fish were able to utilize the protein in the diets optimally. The ADCs of protein and dry matter recorded in the present study were higher than the values reported for juvenile turbot fed rapeseed protein isolates (Nagel et al., 2012), but similar to those reported in common carp fed defatted rubber seed meal (Suprayudi et al., 2015). No significant difference in ADC of lipid were recorded among the various groups, which is also similar to the findings of Kumar et al. (2012).

The various dietary treatments did not significantly influence whole body composition. The similarity observed in the protein content in whole body composition suggest that RPI-based diets had a balanced amino acid profile for optimum growth of $L$. rohita fingerlings. The lower ADC of phosphorus observed among the various groups did not cause any decline in the whole body ash, and this may be due to the low level of phytic acid or dicalcium phosphate incorporated in the diets as additional phosphorus source. Indian major carp has been reported to tolerate phytic acid level below $1 \%$ in the diets with no adverse effect on growth and body composition (Usmani and Jafri 2002; Alvi, 1994), and the levels in all the fed diets were lower than $1 \%$. The insignificant difference in the whole body lipid content detected among the groups were inconsonant with those of Akinleye et al. (2012) and Slawski et al. (2013).

Improvement in the growth performance of animals is a function of the digestive enzyme influence on the digestion processes (Lemieux et al., 1999). In the present study, no significant variation was observed in the activities of digestive enzymes (protease and amylase), signifying that the dietary RPI did not elicit any inhibitory effects on the digestion processes. This may be ascribed to the low level of ANFs present in the diets. Kumar et al. (2012) reported that dietary inclusion of detoxified jatropha and soybean protein isolates did not alter the digestive enzymes activities in common carp. The authors attributed this to the absence of trypsin inhibitors, lectin and addition of phytase in the diets. Similarly, Luo et al. (2012) found no significant differences in the activities of protease and alpha-amylase enzymes in cobia fed rapeseed meal. The non-significant slight decreased in protease activity observed in RPI 50 and RPI 75 correlate with the ADC of protein recorded for this groups. Transaminase (AST and ALT) enzymes catabolize amino acids and transfer amino groups to $\alpha$-keto acids. But when a diet is deficient in essential amino acids, the keto acids may be reduced, thereby resulting in a decreased activities of ALT and AST enzymes (Cheng et al., 2010). In the present study, the activities of both protein metabolism enzymes were found to be similar with the control, indicating that the dietary protein fed met the fish requirement and adequately utilized by the fish. Similar to these, Deng et al. (2015) found no significant differences in the hepatic ALT and AST activities of tilapia fed dietary RSM. On the other hand, Luo et al. (2012) reported that feeding juvenile cobia with increasing dietary rapeseed meal led to a reduction in the activities of ALT and AST enzymes in the liver. LDH enzyme is known to be active when there is an oxygen debt in the tissue, causing pyruvate to be converted to lactate in anaerobic glycolysis (Murray et al., 2000). Increased tissue level activity of this terminal enzyme was reported as the characteristic features of lactic acidosis resulting from the inhibitory effect of cyanide on aerobic metabolism (Speijers, 1993; Okolie and Osagie, 1999), thus, producing a state of histotoxic anoxia. This effects were evidence in cyanide-exposed rabbits and common carp (Okolie and Osagie, 1999; Sadati et al., 2013). Shamna et al. (2015) also observed an increased level activity of LDH enzymes in Labeo rohita fingerlings fed phorbol esters-containing jatropha protein concentrate. Nevertheless, such effects were not seen in the present study where LDH activity in both the muscle and liver were found to decrease with increasing RPI levels, suggesting that there is no shift in aerobic metabolism and the fish were not under hypoxic condition.

Plant products have been reported to have a hypocholesteromic effect in human, terrestrial animal, and fish (Lees et al., 1977; De Schrijver, 1990; Kaushik et al., 1995). The present study clearly showed that dietary RPI inclusion gradually reduce serum cholesterol levels in L. rohita fingerlings. The decreasing trend in cholesterol level with the increasing dietary RPI levels showed a second order polynomial relationship $\left(y=0.0016 x^{2}-0.3299 x+92.047, r^{2}=0.92\right)$. Several authors have also reported the hypocholesteromic effects of plant-based protein in fish and attributed it to the presence of compound that causes increased excretion of bile salts or impede intestinal absorption of cholesterol (Kaushik et al., 2004; Lim and Lee, 2009; Deng et al., 2010; Akinleye et al., 2012). The decreased serum cholesterol level in RPI-fed groups compared to the control hypothetically suggest that rubber seeds may contain some secondary metabolites with hypocholesteromic properties than soybean. The reduction in serum triglyceride levels recorded in RPI fed groups were similar to the findings of Lim and Lee (2009) and Slawski et al. (2012). In contrast, Kumar et al. (2010) and Akinleye et al. (2012) observed increased triglyceride levels in fish fed plant protein based diets against fish meal (control), hence, the variation observed in comparison with our findings may be due to the differences in the major protein source used as control. Elevated blood glucose level has been reported in many fish species fed plant protein based diets due to the higher contents of carbohydrates, and the result obtained in the present study is in accord with other findings (Kikuchi, 1999; Kumar et al., 2010; Akinleye et al., 2012). Conversely, Slawski et al. (2012) detected no significant differences in the plasma glucose levels in rainbow trout fed rapeseed protein concentrate. 


\section{Conclusion}

In conclusion, based on the results obtained in the present study rubber protein isolate could serve as a potential replacer for soybean protein isolate without any detrimental effects on feed palatability, acceptability, growth performance and nutrient utilization. However, it is important to state that this study is a preliminary investigation on the possibility of utilizing RPI as an alternative protein source in the diets of Labeo rohita. Hence, further study is recommended to understand its effect on haemato-immunological response of the fish before its inclusion in aquafeeds.

\section{Conflict of interest}

The authors have no conflict of interest.

\section{Acknowledgments}

We gratefully acknowledge the Director/Vice Chancellor, ICAR-Central Institute of Fisheries Education, Mumbai for providing the facilities for the conduct of this research work. The first author is grateful to the Government of India in partnership with African Union Commission for providing the fellowship to undertake the study. We thank the anonymous reviewers for improving the manuscript.

\section{References}

AOAC (Association of Official Analytical Chemists), 2000. Official Methods of Analysis of the Association Official Analytical Chemists, 17th ed. AOAC, Inc., Arlington, Virginia, USA.

AOAC (Association of Official Analytical Chemists), 1995. Official Methods of Analysis of the Association Official Analytical Chemists, 16th ed. AOAC, Inc., Arlington, Virginia, USA.

Akinleye, A.O., Kumar, V., Makkar, H.P., Angulo-Escalante, M.A., Becker, K., 2012. Jatropha platyphylla kernel meal as feed ingredient for Nile tilapia (Oreochromis niloticus L.): growth, nutrient utilization and blood parameters. J. Anim. Physiol. Anim. Nutr. 96 (1), 119-129, http://dx.doi.org/10.1111/j.1439-0396.2011.01137.x.

Alegbeleye, W.O., Oresegun, A., Akegbejo, Y.S., 2004. Replacement of groundnut cake with rubber seed cake in the diets of Nile tilapia (Oreochromis niloticus). J. Aquat. Sci. 19 (1), 27-31.

Ali, H., Haque, M.M., Chowdhury, M.M.R., Shariful, M.I., 2009. In vitro protein digestibility of different feed ingredients in Thai Koi (Anabas testudineus). J. Bangladesh Agric. Univ. 7, 205-210.

Alvi, A.S., 1994. Adventitious Toxins in Plant Origin Feedstuffs: Quantification and Tolerance Level in Fish Master's Dissertation. Aligarh Muslim University, Aligarh, India.

Bradford, M.M., 1976. A rapid and sensitive method for the quantitation of microgram quantities of protein utilizing the principle of protein-dye binding. Anal. Biochem. 72 (1), 248-254.

Baruah, K., Pal, A.K., Sahu, N.P., Debnath, D., Nourozitallab, P., Sorgeloos, P., 2007. Microbial phytase supplementation in rohu, Labeo rohita, diets enhances growth performance and nutrient digestibility. J. World Aquac. Soc. 8 (1), 129-137.

Cheng, Z.Y., Ai, Q.H., Mai, K.S., Xu, W., Ma, H.M., li, Y., Zhang, J.M., 2010. Effects of dietary canola meal on growth performance, digestion and metabolism of Japanese seabass, Lateolabrax japonicus. Aquaculture 305, 102-108.

Coffey, D., Dawson, K., Ferket, P., Connolly, A., 2016. Review of the feed industry from a historical perspective and implications for its future. J. Appl. Anim. Nutr. 4 (e3), 1-11.

De Schrijver, R., 1990. Cholesterol metabolism in mature and immature rats fed animal and plant protein. J. Nutr. 120 (12), $1624-1632$.

Debnath, D., Pal, A.K., Sahu, N.P., Yengkokpam, S., Baruah, K., Choudhury, D., Venkateshwarlu, G., 2007. Digestive enzymes and metabolic profile of Labeo rohita fingerlings fed diets with different crude protein levels. Comp. Biochem. Physiol. Part B Biochem. Mol. Bio. 146 (1), 107-114.

Deng, J., Mai, K., Ai, Q., Zhang, W., Tan, B., Xu, W., Liufu, Z., 2010. Alternative protein sources in diets for Japanese flounder Paralichthysolivaceus (Temminck and Schlegel): II. Effects on nutrient digestibility and digestive enzyme activity. Aquac. Res. 41 (6), 861-870.

Deng, J., Kangsen, M., Liqiao, C., Haifeng, M., Lu, Z., 2015. Effects of replacing soybean meal with rubber seed meal on growth antioxidant capacity, non-specific immune response, and resistance to Aeromonas hydrophila in tilapia (Oreochromis niloticus x 0 aureus). Fish Shellfish Immunol. 44 436-444.

Devappa, R.K., Swamylingappa, B., 2008. Biochemical and nutritional evaluation of Jatropha protein isolate prepared by steam injection heating for reduction of toxic and antinutritional factors. J. Sci. Food Agric. 88 (5), 911-919.

Dias, J., 1999. Lipid deposition in rainbow trout (Oncorhynchus mykiss) and European seabass (Dicentrarchus labrax L.): nutritional regulation of hepatic lipogenesis. Dr thesis Univ. Porto (Portugal) and Univ. Bordeaux I (France). 190 pp.

Drapeau, G., 1974. Protease from staphylococcus aureus. In: Lorand, B.L. (Ed.), Methods in Enzymology. Academic Press, NY, USA, p. 469 pp.

Eka, H.D., TajulAris, Y., Wan Nadiah, W.A., 2010. Potential use of Malaysian rubber (Hevea brasiliensis) seed as food, feed and biofuel. Int. Food Res. J. 17, 527-534.

El-Sayed, A.-F.M., 1999. Alternative dietary protein sources for farmed tilapia, Oreochromis spp. Aquaculture 179, 149-168.

Francis, G.M., Becker, H.P.S., 2001. Anti-nutritional factors present in plant derived alternate fish feed ingredients and their effects in fish. Aquaculture $199,197-227$.

Furukawa, A., Tsukahara, H., 1966. On the acid digestion method for the determination of chromic oxide as the index substance in the study of fish feed. Bull. Jpn. Soc. Sci. Fish 32, 502-506.

Gao, Y., Shang, C., Maroof, M., Biyashev, R., Grabau, E., Kwanyuen, P., Buss, G., 2007. A modified colorimetric method for phytic acid analysis in soybean. Crop Sci. 47 (5), 1797-1803.

Gao, J., Koshio, S., Ishikawa, M., Yokoyama, S., Mamauag, R.E.P., Han, Y., 2012. Effects of dietary oxidized fish oil with vitamin E supplementation on growth performance and reduction of lipid peroxidation in tissues and blood of red sea bream Pagrus major. Aquaculture 356, 73-79.

Griffiths, D.W., 1991. Condensed tannins. In: D'Mello, F.J.P., Duffus, C.M., Duffus, J.H. Eds., Toxic Substances in Crop Plants. The Royal Society of Chemistry, Thomas Graham House, Science Park, Cambridge CB4 4WF, Cambridge, pp. 180-201.

Hardy, R.W., Barrows, F.T., 2002. Diet formulation and manufacture. In: Halver, J.E., Hardy, R.W. (Eds.), Fish Nutrition. , 3rd ed. Academic Press, San Diego, California, USA, pp. 505-600.

Hassid, W.J., Abraham, S., 1957. Chemical procedures for analysis of polysaccharide. In: Colowich, S.P., Kalplan, N.O. (Eds.), Methods in Enzymology, vol 3. Academic Press. Inc., New York, pp. 35-36.

Hertrampf, J.W., Piedad-Pascual, F., 2000. Handbook on Ingredients for Aquaculture Feeds. Kluwer Academic Publishers, Dordrecht, pp. $482-483$. 
Kaushik, S., Cravedi, J., Lalles, J., Sumpter, J., Fauconneau, B., Laroche, M., 1995. Partial or total replacement of fish meal by soybean protein on growth, protein utilization, potential estrogenic or antigenic effects, cholesterolemia and flesh quality in rainbow trout, Oncorhynchus mykiss. Aquaculture 133 (3), 257-274.

Kaushik, S., Coves, D., Dutto, G., Blanc, D., 2004. Almost total replacement of fish meal by plant protein sources in the diet of a marine teleost, the European seabass, Dicentrarchus labrax. Aquaculture 230 (1), 391-404.

Kikuchi, K., 1999. Partial replacement of fish meal with corn gluten meal in diets for Japanese flounder Paralichthysolivaceus. J. World Aquac. Soc. 30 (3), 357-363.

Kumar, V., Makkar, H.P., Amselgruber, W., Becker, K., 2010. Physiological, haematological and histopathological responses in common carp (Cyprinus carpio L.) fingerlings fed with differently detoxified Jatropha curcas kernel meal. Food Chem. Toxicol. 48 (8), $2063-2072$.

Kumar, V., Makkar, H., Becker, K., 2012. Evaluations of the nutritional value of Jatropha curcas protein isolate in common carp (Cyprinus carpio L.). J. Anim. Physiol. Anim. Nutr. 96 (6), 1030-1043.

Latif, S., Kumar, V., Stadtlander, T., Makkar, H.P.S., Becker, K., 2015. Nutritional and biochemical studies on feeding of hydrolysed and unhydrolysed detoxified Jatropha curcas protein isolate in common carp fingerlings. Aquac. Resear., 1-15, http://dx.doi.org/10.1111/are.12838.

Law, A., 1986. Digestibility of low-cost ingredients in pelleted feed by grass carp (Ctenopharyngodonidella C. et V.). Aquaculture 51 (2), $97-103$.

Lees, A.M., Mok, H.Y., Lees, R.S., McCluskey, M.A., Grundy, S.M., 1977. Plant sterols as cholesterol-lowering agents: clinical trials in patients with hypercholesterolemia and studies of sterol balance. Atherosclerosis 28 (3), 325-338.

Lemieux, H., Blier, P., Dutil, J.D., 1999. Do digestive enzymes set a physiological limit on growth rate and food conversion efficiency in the Atlantic cod (Gadusmorhua). Fish Physiol. Biochem. 20 (4), 293-303.

Lim, S.-J., Lee, K.-J., 2009. Partial replacement of fish meal by cottonseed meal and soybean meal with iron and phytase supplementation for parrot fish Oplegnathusfasciatus. Aquaculture 290 (3), 283-289.

Luo, Y., Ai, Q., Mai, K., Zhang, W., Xu, W., Zhang, Y., 2012. Effects of dietary rapeseed meal on growth performance, digestion and protein metabolism in relation to gene expression of juvenile cobia (Rachycentroncanadum). Aquaculture 368, 109-116.

Makkar, H.P.S., Francis, G., Becker, K., 2008. Protein concentrate from Jatropha curcas screw-pressed seed cake and toxic and anti-nutritional factors in protein concentrate. J. Sci. Food Agric. 88, 1542-1548.

Mambrini, M., Roem, A.J., Carvedi, J., Lalles, J., Kaushik, S., 1999. Effects of replacing fish meal with soy protein concentrate and of DL-methionine supplementation in high-energy, extruded diets on the growth and nutrient utilization of rainbow trout, Oncorhynchus mykiss. J. Anim. Sci. 77 (11), 2990-2999.

Marrufo-Estrada, D.M., Segura-Campos, M.R., Chel-Guerrero, L.A., Betancur-Ancona, D.A., 2013. Defatted Jatropha curcas flour and protein isolate as materials for protein hydrolysates with biological activity. Food Chem. 138 (1), 77-83.

Murray, R.K., Granner, D.K., Mayes, P.A., Rodwell, V.W., 2000. Glycogen metabolism. In: Harper's Biochmistry, 25th edn., pp. 199-207.

Mwachireya, S., Beames, R., Higgs, D., Dosanjh, B., 1999. Digestibility of canola protein products derived from the physical, enzymatic and chemical processing of commercial canola meal in rainbow trout Oncorhynchus mykiss (Walbaum) held in fresh water. Aquac. Nutr. 5 (2), 73-82.

NRS, 2015. Natural Rubber Statistic Report 2015. Malaysia rubber board3-29.

Nagel, F., von Danwitz, A., Tusche, K., Kroeckel, S., van Bussel, C.G.J., Schlachter, M., Adem, H., Tressel, R., Schulz, C., 2012. Nutritional evaluation of rapeseed protein isolate as fish meal substitute for juvenile turbot (Psetta maxima L.)-impact on growth performance, body composition, nutrient digestibility and blood physiology. Aquaculture 356, 357-364.

Okolie, N., Osagie, A., 1999. Liver and kidney lesions and associated enzyme changes induced in rabbits by chronic cyanide exposure. Food Chem. Toxicol. 37 (7), 745-750.

Rick, W., Stegbauer, H.P., 1974. Amylase measurement of reducing groups. In: Bergmeyer, H.V. (Ed.), Methods of Enzymatic Analysis, vol. 2, 2nd ed. Academic Press, New York, pp. 885-889.

SOFIA, 2007. The State of the World Fisheries and Aquaculture 2006. FAO Fisheries and Aquaculture Department, Rome, pp. 1-180.

Sadati, F., Shahsavani, D., Baghshani, H., 2013. Biochemical alterations induced by sublethal cyanide exposure in common carp (Cyprinus carpio). J. Biol. Environ. Sci 7, 65-69.

Saetae, D., Suntornsuk, W., 2011. Toxic compound, anti-nutritional factors and functional properties of protein isolated from detoxified Jatropha curcas seed cake. Int. J. Mol. Sci. 12 (1), 66-77.

Savoie, L., Galibois, I., Parent, G., Charbonneau, R., 1988. Sequential release of amino acids and peptides during in vitro digestion of casein and rapeseed proteins. Nutr. Res. 8 (11), 1319-1326.

Schanderi, S., 1970. Methods in Food Analysis. Academic press, New York, pp. 709.

Schulz, C., Wickert, M., Kijora, C., Ogunji, J., Rennert, B., 2007. Evaluation of pea protein isolate as alternative protein source in diets for juvenile tilapia (Oreochromis niloticus). Aquac. Res. 38 (5), 537-545.

Shamna, N., Sardar, P., Sahu, N., Pal, A., Jain, K., Phulia, V., 2015. Nutritional evaluation of fermented Jatropha protein concentrate in Labeo rohita fingerlings. Aquac. Nutr. 21 (1), 33-42.

Sharma, B.B., Saha, R.K., Saha, H., 2014. Effects of feeding detoxified rubber seed meal on growth performance and haematological indices of Labeo rohita (Hamilton) fingerlings. J. Anim. Feed Sci.Tech. 193, 84-92.

Slawski, H., Adem, H., Tressel, R.-P., Wysujack, K., Koops, U., Kotzamanis, Y., Schulz, C., 2012. Total fish meal replacement with rapeseed protein concentrate in diets fed to rainbow trout (Oncorhynchus mykissWalbaum). Aquac. Int. 20 (3), 443-453.

Slawski, H., Nagel, F., Wysujack, K., Balke, D., Franz, P., Schulz, C., 2013. Total fish meal replacement with canola protein isolate in diets fed to rainbow trout (Oncorhynchus mykiss W.). Aquac. Nutr. 19 (4), 535-542.

Speijers, G., 1993. Cyanogenic glycosides. Food Addit. Ser. 30.

Storebakken, T., Refstie, S., Ruyter, B., 2000. Soy products as fat and protein sources in fish feeds for intensive aquaculture. In: Drackly, J.K. (Ed.), Soy in Animal Nutrition. Federation of Animal Science Societies, Savoy, IL, pp. 127-170.

Suprayudi, M.A., Inara, C., Ekasari, J., Priyoutomo, N., Haga, Y., Takeuchi, T., Satoh, S., 2015. Preliminary nutritional evaluation of rubber seed and defatted rubber seed meals as plant protein sources for common carp Cyprinus carpio L. juvenile diet. Aquac. Resear. 46, 2972-2981, http://dx.doi.org/10.1111/are.12452.

Tacon, A.G., Metian, M., 2008. Global overview on the use of fish meal and fish oil in industrially compounded aquafeeds: trends and future prospects. Aquaculture 285, 146-158.

UN-DESA, 2015. World Population Prospects: The 2015 Revision, Key Findings and Advance Tables. In. Working Paper No ESA/P/WP. 241, United Nations, Department of Economic and Social Affairs, Population Division, New York.

Usmani, N., Jafri, A.K., 2002. Influence of dietary phytic acid on the growth, conversion efficiency, and carcass composition of mrigal, Cirrhinusmrigala fry. J. World Aquac. Soc. 33, 199-204.

Wanasundara, J.P., 2011. Proteins of Brassicaceae oilseeds and their potential as a plant protein source. Crit. Rev. Food Sci. Nutr. 51 (7), 635-677.

Watson, A.M., Kissil, G.W., Barrows, F.T., Place, A.R., 2012. Developing a plant-based diet for cobia Rachycentroncanadum. Int. Aquafeed 15, 34-38.

Wooten,I.J.P., 1964. Microanalysis. Churchill, J., Churchill, A. Medical Biochemistry, 4th ed. London 101-107.

Wroblewski, F., Ladue, J.S., 1955. LDH activity in blood. Pro. Soc. Exp. Bio. Med. 90, 210-213.

Xu, Q.Y., Wang, C.A., Zhao, Z.G., Luo, L., 2012. Effects of replacement of fish meal by soy protein isolate on the growth, digestive enzyme activity and serum biochemical parameters for juvenile amur sturgeon (Acipenserschrenckii). Asian Aust. Anim. Sci. 25 (11), 1588-1594.

Yue, Y., Zhou, Q., 2008. Effect of replacing soybean meal with cottonseed meal on growth, feed utilization, and hematological indexes for juvenile hybrid tilapia Oreochromis niloticus $\times$ O. aureus. Aquaculture 284, 185-189. 